This document is the accepted manuscript version of the following article:

Mina, M., del Río, M., Huber, M.O., Thürig, E., \& Rohner, B. (2018). The symmetry of competitive interactions in mixed Norway spruce, silver fir and European beech forests. Journal of Vegetation Science. https://doi.org/10.1111/jvs.12664

DR. MARCO MINA (Orcid ID : 0000-0002-7489-7688)

Article type : Research article

Kerry Woods

Coordinating Editor: Dr. Kerry Woods

Running head: Symmetry of competition in spruce-fir-beech forests

\title{
The symmetry of competitive interactions in mixed Norway spruce, silver fir and European beech forests
}

Marco Mina ${ }^{1,2}$, Miren del Río ${ }^{3,4}$, Markus O. Huber ${ }^{1}$, Esther Thürig ${ }^{1}$, and Brigitte Rohner ${ }^{1}$

${ }^{1}$ Swiss Federal Institute for Forest, Snow and Landscape Research WSL, Zürcherstrasse 111, 8903 Birmensdorf, Switzerland

${ }^{2}$ Centre for Forest Research (CEF), Département des Sciences Biologiques, Université du Québec à Montréal, Montréal, Québec H3C 3P8, Canada

${ }^{3}$ Department of Silviculture and Forest Management, INIA, Forest Research Centre INIA-CIFOR Forest Research Centre, 28040, Madrid, Spain

${ }^{4}$ Sustainable Forest Management Research Institute, University of Valladolid - INIA

Corresponding author:

Marco Mina

Centre for Forest Research (CEF),

Département des Sciences Biologiques, Université du Québec à Montréal (UQAM)

C.P. 8888, Succ. Centre-Ville

Montréal, Québec H3C 3P8

Canada

Email address: marco.mina@wsl.ch; marco.mina@alumni.ethz.ch (M. Mina)

This article has been accepted for publication and undergone full peer review but has not been through the copyediting, typesetting, pagination and proofreading process, which may lead to differences between this version and the Version of Record. Please cite this article as doi: $10.1111 /$ jvs. 12664

This article is protected by copyright. All rights reserved. 


\begin{abstract}
Questions: We aim for a better understanding of the different modes of intra- and inter-specific competition in two- and three-species mixed forests. How can the effect of different modes of competitive interactions be detected and integrated in individual tree growth models? Are species interactions in spruce-fir-beech forests more associated with size-symmetric or size-asymmetric competition? Do competitive interactions between two of these species change from two- to threespecies mixtures?
\end{abstract}

Location: Temperate mixed species forests of Norway spruce, silver fir and European beech in Central Europe (Switzerland).

Methods: We used data from the Swiss National Forest Inventory to fit basal area increment models at the individual tree level including the effect of ecological site conditions and indices of sizesymmetric and size-asymmetric competition. Interaction terms between species-specific competition indices were used to disentangle significant differences in species interactions from two- to threespecies mixtures.

Results: The growth of spruce and fir was positively affected by increasing proportions of the other species in spruce-fir mixtures, but negative effects were detected at increasing presence of beech. We found competitive interactions for spruce and fir to be more related to size-symmetric competition, indicating that species interactions might be more associated to competition for belowground resources. Under constant amounts of stand basal area, the growth of beech clearly benefited from the increasing admixture of spruce and fir. For this species, patterns of size-symmetric and sizeasymmetric competitive interactions were similar, indicating that beech is a strong self-competitor for both aboveground and belowground resources. Only for silver fir and beech we found significant changes in species interactions from two- to three-species mixtures, but these were not as prominent as the effects due to differences between intra- and inter-specific competition.

Conclusions: Species interactions in spruce-fir-beech, or other mixed forests, can be characterized depending on the mode of competition, allowing interpretations whether they occur mainly at aboveor belowground level. Our outcomes illustrate that species-specific competition indices can be integrated in individual tree growth functions to express the different modes of competition between species, and they highlight the importance of considering the symmetry of competition alongside with competitive interactions in models aiming at depicting growth in mixed-species forests.

Keywords: above and belowground competition; basal area increment; intra and inter specific interactions; mixed species forests; mixing effects; national forest inventory; nonlinear mixed effect models; species interactions; size-symmetric and size-asymmetric competition

This article is protected by copyright. All rights reserved. 


\section{Introduction}

The interest in mixed-species forests has been rising during the past years. There is a broad consensus that forests with higher species diversity are likely to be more resistant and resilient to climate change stressors and ecological disturbances (Fares et al. 2015; Seidl et al. 2016). Additionally, mixedspecies forests have potential to deliver higher levels of ecosystem services (Knoke et al. 2008; Gamfeldt et al. 2013) and, under certain conditions, can also be more productive than single-species stands (Pretzsch et al. 2013a; Toigo et al. 2015; Mina et al. 2018). Enhancing our knowledge on how tree species interact with each other in mixed stands is fundamental in the perspective of implementing adaptation measures to climate change, such as increasing species richness and replacing monospecific, high-risk forest stands (Ammer 2017; Bauhus et al. 2017).

Species interactions in mixed forests are often explored by comparing effects of intra- and interspecific competition on individual tree growth (Manso et al. 2015). For a given tree species growing in a mixed stand, inter-specific competition might sometimes be lower than intra-specific competition due to due to facilitation or a differentiation in niche complementarity (Cavard et al. 2011). In this case, it is typically said that there are positive complementary effects of the presence of one species on the growth of the other (Forrester \& Bauhus 2016). There are several mechanisms that can lead to positive complementary effects, from reductions in crown interference due to spatial stratification (Pretzsch 2014), to improved nutrient conditions thanks to a more efficient exploitation of soil volumes or litter deposition (Rothe \& Binkley 2001). As these processes can occur simultaneously, it is very difficult to disentangle the specific mechanism that is responsible for facilitative or competitive effects.

One possible way to better understand how species interact with each other is to study the process of competition based on symmetry. According to Weiner (1990), resource uptake among competitors can be proportional to their own size, that is, competition is size-symmetric. If resource uptake is not relative to size, for example when larger plants obtain all the resources to the detriment of smaller individuals, competition is defined as size-asymmetric. In the literature there is a general consensus that plants compete asymmetrically for light and symmetrically for belowground resources such as water and soil nutrients (Weiner 1990; Casper \& Jackson 1997; Larocque et al. 2013). Since the detection of mechanisms responsible for competition with direct measurements is difficult due to the complexity of processes involved for resource uptake, indirect methods based on growth models and competition indices have been increasingly proposed as an alternative (Weiskittel et al. 2011).

However, to date functions in statistical tree growth models rarely consider these different modes of competition (Pretzsch \& Biber 2010; Larocque et al. 2013). In addition, modelling methods which include size-symmetric and size-asymmetric components have mainly been applied in single-species stands (Cordonnier \& Kunstler 2015; Bourdier et al. 2016). Only few investigations have been

This article is protected by copyright. All rights reserved. 
extended to explore size-symmetry of competition in two- or multi-species forests (Coates et al. 2009; Riofrio et al. 2017).

We focus on three major species in Europe: Norway spruce (Picea abies L., hereafter spruce), silver fir (Abies alba Mill., hereafter fir) and European beech (Fagus sylvatica L., hereafter beech). These species have a high ecological and economical value in central and eastern Europe (Ellenberg 1988). More importantly, spruce-fir-beech mixtures connect beech and broadleaves-dominated forests in the lowland with spruce and conifers-dominated subalpine tree communities, and they represent a key source of ecosystems goods and services in montane and sub-montane regions (Pretzsch et al. 2015). Previous results on mixing effects for these species were quite heterogeneous, with complementary effects varying strongly with climate, stand and site conditions (Forrester 2014; Mina et al. 2018). Past investigations carried out mostly on mixtures of two of these species showed that beech generally performs better when growing in mixtures with conifers thanks to a reduced intraspecific competition (Pretzsch et al. 2010; Bosela et al. 2015) and under certain conditions spruce and fir were found to benefit from growing in two-species mixtures rather than in pure stands (Forrester et al. 2013).

In this study we aim for a better understanding of the different modes of intra- and inter-specific competition in mixed spruce-fir-beech forests. To this purpose, we introduce the terms size-symmetric mixing effects (SSME) and size-asymmetric mixing effects (SAME) to indicate whether there are positive or negative complementary effects between tree species and if these are more associated to belowground (size-symmetric) or to aboveground resources (size-asymmetric). We used individual tree models fitted to data from the Swiss National Forest Inventory to explore the following research questions:

i. How can size-symmetric and size-asymmetric competition be accounted for in functions of individual tree growth models?

ii. Are species interactions in spruce-fir-beech forests more associated with size-symmetric or size-asymmetric competition?

iii. Do competitive interactions between two of these species change from two- to three-species mixtures?

\section{Materials and methods}

\section{Data}

To explore size-symmetric and size-asymmetric mixing effects we selected forest stands measured in the Swiss National Forest Inventory (NFI). Spruce, fir and beech are the species with the largest number of observations in the NFI and represent the most common mixture types in Switzerland. To study size-symmetric and size-asymmetric mixing effects, we retained sampling plots with these three species (Fig.1): monospecific (basal area of one of the three species $>95 \%$; absence of the two other

This article is protected by copyright. All rights reserved. 
investigated species), two-species mixture (basal area of two of the three species $>95 \%$; absence of the third species), three-species mixture (basal area of the three investigated species together $>95 \%$ ). Additional description on the Swiss NFI and plots selection can be found in Appendix S2. The main characteristics of our dataset by species and stand composition are given in Table 1.

Individual tree and plot-level variables such as diameter at breast height (DBH), basal area increment (BAI, $\mathrm{cm}^{2} \mathrm{ha}^{-1} \mathrm{yr}^{-1}$ ), arithmetic mean value of the 100 largest DBH per ha (DDOM, cm), and stand structure types (TYP, categorical; 0 for even- and 1 for uneven-aged forest) were derived from the NFI database (Traub et al. 2017). Following the approach described in Mina et al. (2018), we obtained variables expressing climate (temperature, moisture index, solar radiation), site topography (slope, profile curvature, northness and eastness index), soil acidity $(\mathrm{pH})$, available soil water holding capacity, release effects due to management (RE), and atmospheric nitrogen deposition from multiple sources (for details see Appendix S2, Rohner et al. 2016; Rohner et al. 2017).

\section{Indices for size-symmetric/size-asymmetric competition and mixing effects}

As a proxy for size-symmetric competition (competition for belowground resources) we used a simple distance-independent index, i.e. the total basal area of all trees within the sampling plot of the target tree (BA, $\mathrm{m}^{2} \mathrm{ha}^{-1}$ ) while for size-asymmetric (competition for light) we used the sum of the basal area of trees with larger diameters than the target tree in the plot $\left(\mathrm{BAL}, \mathrm{m}^{2} \mathrm{ha}^{-1}\right)$. These formulations have been used in several studies to investigate the different modes of competition at the individual tree level (Weiskittel et al. 2011; Cordonnier \& Kunstler 2015). Both indices, however, treat each species as an equal competitor considering that all species compete similarly for light or belowground resources. To explore the influence of species mixture on tree growth, and thus to analyse SSME and SAME, we split these two indices into species-specific components. Size-symmetric mixing effects were expressed by the basal area of trees of a given species within the sampling plot of the target stem $\left(\mathrm{BA}_{\mathrm{sS}}, \mathrm{m}^{2} \mathrm{ha}^{-1}\right)$ while size-asymmetric mixing effects by the basal area of trees of a given species larger than the target tree $\left(\mathrm{BAL}_{\mathrm{SS}}, \mathrm{m}^{2} \mathrm{ha}^{-1}\right)$. Taking spruce as an example, the index $\mathrm{BA}_{\mathrm{SS} \text {-spruce }}$ therefore indicates the intra-specific size-symmetric competition component, while $\mathrm{BA}_{\mathrm{SS} \text {-fir }}$ and $\mathrm{BA}_{\mathrm{SS} \text { - }}$ beech denote the two inter-specific size-symmetric competition components. Ranges of $\mathrm{BA}_{\mathrm{SS}}$ and $\mathrm{BAL}_{\mathrm{SS}}$ for each species are shown in Fig.S2 of Supporting Information. See Appendix S2 on the choice of distance-independent indices.

\section{Modelling methods}

\section{Model structure}

We used the NFI dataset complemented with the climatic and site variables described above to fit non-linear mixed-effect models (Pinheiro \& Bates 2000) with the package nlme in R 3.4.0 (Pinheiro et al. 2017; R Core Team 2017) for spruce, fir and beech. The models included BAI of individual trees as the dependent variable and were based on the growth functions initially developed for the empirical

This article is protected by copyright. All rights reserved. 
forest scenario model Massimo (Kaufmann 2001; Thürig et al. 2005). Our initial models were built from the climate-sensitive "full models" described in Rohner et al. (2017), where a wide range of explanatory variables was evaluated to model possible effects on BAI. As a measure of competition, they selected Reineke's stand density index. However, differently from Rohner et al. (2017), we decided for the present study to exclude a priori the stand density index calculated according to Reineke (1933), as this index would require species-specific coefficients for the self-thinning-rule in the case of stands with different species compositions. To avoid this issue, we preferred to use basal area to characterize competition (see above). The functions followed the form:

$$
B A I=e^{b_{1} \times\left(1-e^{b_{2} \times D B H}\right)} \times e^{f\left(V_{1}, \ldots, V_{i}\right)}+\epsilon
$$

where $b_{1}$ and $b_{2}$ are model coefficients, $\epsilon$ is the residual error, and $f\left(V_{1}, \ldots, V_{i}\right)$ is a function of $i$ explanatory variables $\left(V_{1}, \ldots, V_{i}\right)$, including a random intercept with NFI plots as a grouping factor $\left(b_{p l o t}\right)$ :

$$
f\left(V_{1}, \ldots, V_{i}\right)=\beta_{0}+\beta_{1} V_{1}+\cdots+\beta_{i} V_{i}+b_{p l o t}
$$

where $\beta_{0}$ is the estimated fixed intercept and $\beta_{1, \ldots, i}$ are model coefficients for each explanatory variable (Mina et al. 2018).

\section{Size-symmetric and size-asymmetric mixing effects}

To test whether species interactions in spruce-fir-beech forests are more associated with symmetric or asymmetric competition, we included the indices $\mathrm{BA}, \mathrm{BAL}, \mathrm{BA}_{\mathrm{SS}}$ and $\mathrm{BAL}_{\mathrm{SS}}$ in the function described in Eq.2. As a first step we tested whether models with intra- and inter-specific sizesymmetric and size-asymmetric competition indices $\left(\mathrm{BA}_{\mathrm{SS}}\right.$ and $\left.\mathrm{BAL} \mathrm{L}_{\mathrm{SS}}\right)$ were more explanatory than their total components (BA and BAL). For this we followed a similar approach as presented in del Río et al. (2014) and compared the performance of different competition structures using combinations of the four competition indices reported above. At the same time, we included interaction terms between the species-specific competition indices $\left(\mathrm{BA}_{\mathrm{SS}}, \mathrm{BAL}_{\mathrm{SS}}\right)$. The integration of interaction terms was needed to understand if there were significant differences in species interactions from two- to threespecies mixtures (i.e., when the third investigated species is also present), and thus to identify whether the proportion between the two other species has an influence on the growth of the target species (e.g., fir and beech on spruce). To test this, we allowed interactions between the two competition variables expressing inter-specific competition (e.g., for spruce between $\mathrm{BA}_{\mathrm{SS}-\text {-fir }}$ and $\mathrm{BA}_{\mathrm{SS}-\text { beech }}$ and/or $\mathrm{BAL} \mathrm{SS}_{\mathrm{SS} \text {-fir }}$ and $\left.\mathrm{BAL}_{\mathrm{SS}-\text { beech }}\right)$. We decided to focus on ecologically meaningful interaction terms and to avoid triple interactions that are often problematic to interpret.

We fitted the full models for spruce, fir and beech developed by Rohner et al. (2017) but expanding competition with different combinations of competition structures and interactions terms, for a total of nine combinations: (1) $\mathrm{V}_{1}+\ldots+\mathrm{V}_{\mathrm{i}}+\mathrm{BA}+\mathrm{BAL}$; (2) $\mathrm{V}_{1}+\ldots+\mathrm{V}_{\mathrm{i}}+\mathrm{BA}+\mathrm{BAL}_{\mathrm{SS}}$; (3) 
$\mathrm{V}_{1}+\ldots+\mathrm{V}_{\mathrm{i}}+\mathrm{BA}_{\mathrm{SS}}+\mathrm{BAL} ;(4) \mathrm{V}_{1}+\ldots+\mathrm{V}_{\mathrm{i}}+\mathrm{BA}_{\mathrm{SS}}+\mathrm{BAL}_{\mathrm{SS}} ;(5) \mathrm{V}_{1}+\ldots+\mathrm{V}_{\mathrm{i}}+\mathrm{BA}_{\mathrm{SS}}+\mathrm{BAL}+$ $\mathrm{BA}_{\mathrm{SS} \text {-inter1 } 1}: \mathrm{BA}_{\mathrm{SS} \text {-inter2} 2}$; (6) $\mathrm{V}_{1}+\ldots+\mathrm{V}_{\mathrm{i}}+\mathrm{BA}+\mathrm{BAL}_{\mathrm{SS}}+\mathrm{BAL}_{\mathrm{SS} \text {-inter1 }}: \mathrm{BAL}_{\mathrm{SS} \text {-inter2}}$; (7) $\mathrm{V}_{1}+\ldots+\mathrm{V}_{\mathrm{i}}+$ $\mathrm{BA}_{\mathrm{SS}}+\mathrm{BAL}_{\mathrm{SS}}+\mathrm{BA}_{\mathrm{SS} \text {-interl }}: \mathrm{BA}_{\mathrm{SS}-\text { inter2 }} ;(8) \mathrm{V}_{1}+\ldots+\mathrm{V}_{\mathrm{i}}+\mathrm{BA}_{\mathrm{SS}}+\mathrm{BAL}_{\mathrm{SS}}+\mathrm{BAL}_{\mathrm{SS} \text {-interl }}: \mathrm{BAL}_{\mathrm{SS}-\text { inter } 2} ;$ (9) $\mathrm{V}_{1}+\ldots+\mathrm{V}_{\mathrm{i}}+\mathrm{BA}_{\mathrm{SS}}+\mathrm{BAL}_{\mathrm{SS}}+\mathrm{BA}_{\mathrm{SS} \text {-inter1 }}: \mathrm{BA}_{\mathrm{SS} \text {-inter} 2}+\mathrm{BAL}_{\mathrm{SS} \text {-inter1 }}: \mathrm{BAL}_{\mathrm{SS}-\text { inter2}}$. If a model including the total competition components (BA, BAL) outperforms a model with intra- and inter-specific indices, this indicates similar intra- and inter-specific competition and that there are no SSME and SAME to be investigated. If the inclusion of intra- and inter-specific indices results in a better fit, this means that there are mixing effects which can be more related to below-ground resources (sizesymmetric) or above-ground competition (size-asymmetric).

Models with the different competition structures (1. - 9. above) were ranked by their AICc values (Burnham \& Anderson 2003). The model with lowest AICc was used for the subsequent variable selection process where a stepwise backward approach was applied to remove variables with low explanatory power. This was accomplished step by step by comparing the AICc value excluding one variable at a time from each model. The variable selection process included all variables incorporated in the function $f\left(V_{1}, \ldots, V_{i}\right)$ (i.e., climatic, site-specific variables and competition indices; Appendix $\mathrm{S} 2)$. The final models were designated if excluding further variables did not reduce the AICc anymore. The final models were then used to estimate BAI under different stand/species composition scenarios with varying $\mathrm{BA}_{\mathrm{SS}}$ and $\mathrm{BAL}_{\mathrm{SS}}$ and with climatic and site variables fixed at their mean (Appendix S3). Goodness of fit of the models was evaluated using the relative root-mean-square error (RMSE), the percent bias and the $\mathrm{R}^{2}$ between observed and predicted values of BAI. Graphical comparison of observations and model predictions was presented in Fig. S4.

\section{Results}

\section{Integration of size-symmetric and size-asymmetric mixing effects}

For both spruce and fir, the competition structure that led to the best model was the one in which sizesymmetric competition was split into intra- and inter-specific components (Table 2). This was

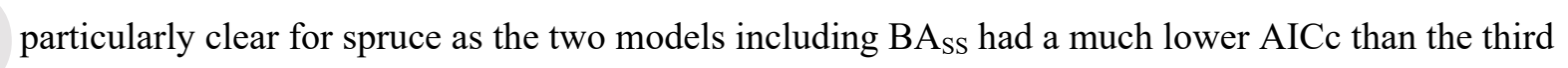
best model with the total BA index (Table S2). The consideration of the species-specific indices of size-asymmetric competition $\left(\mathrm{BAL}_{\mathrm{SS}}\right)$ did not result in better models than the ones with the total BAL index (absence of SAME) for these two species. The best model for spruce did not include any interaction term between inter-specific $\mathrm{BA}_{S S}$ or $\mathrm{BAL}_{S S}$ while in the case of fir the interaction term between inter-specific $\mathrm{BA}_{\mathrm{SS}}$ indices was included in the best model. From the inspection of the Akaike weights (Wagenmakers \& Farrell 2004), the best model for fir - including the interaction term - was only 1.4 times more likely to be the best model than the next-best model (no interaction) and the delta AICc between these two models was relatively low (0.73). This suggests that the effect of

This article is protected by copyright. All rights reserved. 
the proportion between the basal area of spruce and beech in a three-species mixture may not have a strong influence on fir's BAI (see further below).

In the case of beech, the best model included both size-symmetric and size-asymmetric competition divided into species-specific components. The importance of the indices split into species-specific components is evident from the ranking of the models with different competition structures: the first four best models all included $\mathrm{BA}_{\mathrm{SS}}$ and $\mathrm{BAL}_{\mathrm{SS}}$ and there was a large delta AICc (134.91) between the best model and the one with total BA and total BAL (Table S2). Moreover, the best model for beech included the interaction term between $\mathrm{BAL}_{\mathrm{SS}}$ of spruce and fir. The importance of considering interaction terms for beech was confirmed by the fact that the second-best model, including interaction terms as well, was 5.1 times more likely to be a better model than the third best model that did not include any interactions.

\section{Basal area increment models and patterns of SSME and SAME}

In the process of variable selection, two to five explanatory variables by species were removed from the "full models" including competition components (spruce: TYP, EAST; fir: CURV, EAST, NORTH, RE, TYP, MI; beech: EAST, AWC, RE, NORTH). Details are given in Appendix S2. None of the competition indices (BA, BAL, $\mathrm{BA}_{S S}$ and $\mathrm{BAL}_{S \mathrm{~S}}$ ) were removed during this process, confirming the highly explanatory power of the indices and the robustness of the competition structure in each final model.

The estimated coefficients of the final models are shown in Table 2. Estimates of the climatic, stand and site variables on individual tree growth were plausible for all three species. For instance, DDOM, SLP and PH had a negative effect on tree growth of each species while increasing TEMP, AWC, MI, SR and CURV positively affected basal area increment for two or all three species. Other factors had a positive effect on tree growth of spruce (RE, NORTH) and only the effect of NDEP varied depending on the species (negative for spruce and fir, positive for beech). Since the focus of the current study is on SSME and SAME, we refer to the studies by Rohner et al. (2017) and Mina et al. (2018) for a full description and interpretation of the effects of the single drivers on tree growth.

Coefficients of the competition indices for size-symmetric competition $\left(\mathrm{BA}_{\mathrm{SS}}\right)$ indicated strong differences between intra- and inter-specific competition, as well as differences between the two species representing inter-specific competition (Table 2). In the case of spruce, size-symmetric competition of fir was found to be lower than intra-specific competition, denoting positive SSME of fir on spruce. Thus, at increasing proportions of basal area of fir in a spruce-fir stand, spruce BAI was found to increase (stand type SF in Fig. 2a). However, the effect of size-symmetric competition of beech was more than twice the one of spruce, indicating strong negative SSME of beech on spruce, and resulting in a strong decrease of spruce BAI at increasing proportions of beech in a spruce-beech stand (stand type SB in Fig. 2a). In the three-species mixture, positive SSME due to the presence of fir contributed to a slight increase of spruce BAI when the proportions of beech remain under a certain

This article is protected by copyright. All rights reserved. 
threshold (e.g., 20\%; stand type SFB8020 in Fig. 2a). At increasing proportions of beech in a sprucefir-beech stand, spruce BAI was negatively affected (stand types SFB5050, SFB2080 in Fig. 2a). For fir, the coefficient for spruce $\left(\mathrm{BA}_{\mathrm{SS}-\text { spruce }}\right)$ was slightly lower than the one expressing intra-specific competition (BA $\left.\mathrm{BS}_{\mathrm{SS} \text {-spruce }}\right)$. Similar as for spruce, fir's BAI was thus positively affected at increasing proportions of spruce in mixed fir-spruce stands (FS in Fig. 2b) but it was reduced as soon as beech was present in the stand, even at low proportions (FSB8020 in Fig. 2b). The interaction term BAssspruce:BAss-beech results in a slightly nonlinear effect of the competitor's proportions on the BAI of fir in the three-species mixture (Fig. 2b). In the case of beech, both coefficients of inter-specific sizesymmetric competition were lower than the intra-specific one, denoting positive SSME for beech when mixed with spruce and/or fir. The strongest increase of beech's growth was found when mixed with fir only, while the weakest increase was found in admixture with spruce only (Fig. 2c). In the three-species mixture, SSME on beech BAI increased with increasing amounts of fir.

With regard to size-asymmetric competition, the final models for spruce and fir did not include species-specific indices. Individual tree growth of spruce and fir was found to decrease with increasing BAL but the effect of increasing size-asymmetric competition was only due to the total BAL coefficient (Fig. 3). For beech, however, we found different effects on BAI depending on the species composition of the larger competitors (Fig. 4; Table 2). The smallest growth reduction occurred when BAL was composed of spruce trees only, followed by the case when the pool of larger competitors was made of $80 \%$ spruce and $20 \%$ fir (SF8020). Similar reductions were observed if larger competitors were only fir or spruce-fir in different proportions (SF5050, SF2080). Nonetheless, the highest reduction in beech BAI occurred when larger competitors were composed of beech, due to the higher intra-specific than inter-specific asymmetric competition. In the three-species mixture, the higher the proportions of beech in the larger competitors, the more negatively growth was affected (Fig. 4, dotted lines). When both spruce and fir were present among larger competitors, we detected the effect of the interaction term $\mathrm{BAL}_{\mathrm{SS} \text {-spruce }} \mathrm{BAL}_{\mathrm{SS}-\text { fir }}$ (e.g, in Fig. 4 beech BAI was more negatively affected in SF5050 and SF2080 than in F).

\section{Discussion}

The outcomes of this study illustrate that species-specific competition indices could be integrated in individual tree growth models to express the different modes of competition among species in mixed forests. We could also show that species interactions in temperate spruce-fir-beech forests differ depending on the mode of competition, and that although competitive interactions for fir and beech change from two- to three-species mixtures, this effect is weak compared to the effect due to the differences between intra- and inter-specific competition.

This article is protected by copyright. All rights reserved. 


\section{Modes of competitive interactions in spruce-fir-beech forests}

For all three investigated species we detected clear differences between intra- and inter-specific competition. This indicates the presence of mixing effects in two- and three-species mixtures of spruce, fir and beech. These effects, however, differed depending on the mode of competition.

In the case of spruce and fir, our results showed that individual tree growth of both species is larger in spruce-fir mixtures than in the respective monocultures. In particular, spruce benefited more in terms of growth than fir in spruce-fir mixtures (Fig.2a, b). This is consistent with results from previous studies where these two conifers were found to benefit from growing in the respective twospecies mixture rather than in pure stands (Forrester et al. 2013 at single-tree level; Toigo et al. 2015 at stand-level). Vallet and Perot (2011) showed that fir generally grows better in spruce-fir mixtures than in pure stands but Huber et al. (2014) demonstrated that a positive complementarity occurred only under certain climatic and site conditions, underlining the importance to assess mixing effects in relation to site variability (see further below). No evident differences between intra- and inter-specific size-asymmetric competition were found for spruce and fir. This indicate that interactions between spruce and fir are likely associated to size-symmetric competition. Therefore, although competition for light remain one of the prominent limiting factors for spruce and fir (variable BAL was yet highly significant), it seems that positive competitive interactions for these two species might be due to a more efficient use of belowground rather than aboveground resources. Forrester et al. (2013) suggested that silver fir may have a competitive advantage to access soil water thanks to a better ability than spruce to develop deep root systems. In line with our results, Lebourgeois et al. (2013) suggested that positive effects of the presence of spruce on fir may be due to a reduced competition for water or an improved soil water availability thanks to a more efficient vertical stratification of root systems (but see Forrester \& Albrecht 2014). A possible reason for the absence of significant SAME for spruce might be due to the characteristics of the dataset on which our models were fitted. In most of the included stands the largest trees were spruce (Fig. S3), resulting in a BAL for spruce dominated by intraspecific competition. This may explain why we found no benefits from splitting BAL into species-specific components. For fir, the absence of significant SAME might be due the large shadetolerance of this species, which may be less sensitive to the difference in crown morphology among species, as it is adapted to grow at low light levels (Bourdier et al. 2016). Several studies found that canopy structuring in mixed stands can be one of the reasons of stand overyielding (Bauhus et al. 2004; Pretzsch 2014). The fact that the crown structure of spruce and fir do not differ as much as from beech might be another explanation why we did not detect aboveground complementarity between the two conifers.

When spruce and fir were admixed with beech we detected negative effects of increasing proportions of beech on individual tree growth of both conifers. Since only SSME were significant for spruce and fir, the negative effects of beech on the growth of the two conifers could be due to competition of rooting systems and belowground use rather than for aboveground resources. Several

This article is protected by copyright. All rights reserved. 
studies indicated that beech has a higher ability to make morphological and physiological adjustments of its root system compared to competing species in mixed stands (Büttner \& Leuschner 1994; Curt \& Prévosto 2003). In particular, Bolte et al. (2013) demonstrated that beech can adopt a flexible root foraging strategy to access soil resources less exploited by the competing species while spruce maintains a conservative strategy by keeping a shallow vertical fine root distribution in both pure and mixed spruce-beech stands. Also Pretzsch et al. (2010) concluded that the reduction of growth of spruce admixed with beech on fertile sites can be caused by competition for root space and soil resources between these two species. Although we did not directly measured root systems, our outcomes support earlier findings that beech fine rooting may be facilitated in the presence of spruce whereas the competitive pressure on spruce increases when mixed with beech (Bolte \& Villanueva 2006). Our results on spruce-beech stands also support the study by Toigo et al. (2015), who showed that these mixtures are more productive than the respective monocultures but that the observed standlevel overyielding was due to enhanced growth of beech to the detriment of spruce.

Unlike spruce-beech mixture, which are quite common in the literature, studies on fir-beech mixtures are rather scarce. Common ecological knowledge suggests that fir is the most capable conifer to compete with beech (Ellenberg 1988) and those few investigations on this mixture type concluded that fir's growth was positively affected by beech admixture (Bosela et al. 2015; Toigo et al. 2015). Lebourgeois et al. (2013) attributed a positive effect of beech on fir to the different strategies of water extraction by roots of the two species; however, these facilitative effects were detected in drought-prone sites only, which are missing in our study region (Table 1). Our results suggest that individual tree growth of fir in Switzerland responds negatively to increased proportions of beech, but only on the size-symmetric component. Since we did not investigate if this effect occurs only under particular site and soil conditions and given that fir is not influenced by the species composition of larger competitors, our results do not disagree with previous findings showing over yielding in fir-beech stands (Toigo et al. 2015). To better disentangle patterns of mixing effects between silver fir and beech, further investigations on this mixture type would be highly valuable, particularly considering interactions between competition and site conditions.

At constant amounts of stand basal area, our results indicate that the growth of beech in two- and three-species mixtures clearly benefits from an increasing admixture with spruce and fir. The model for beech was the only one including similar patterns for SSME and SAME. These results suggest that beech has a competitive advantage in mixtures for the use of both below and aboveground resources (Pretzsch et al. 2010). Many studies demonstrated the low self-tolerance of beech and its severe intraspecific asymmetric competition due to high lateral expansion (Pretzsch 2014; Pretzsch \& Schutze 2016). Our study does not only confirm that beech is a strong self-competitor for aboveground resources but also highlights that it has a strong belowground competitive ability (Rewald \& Leuschner 2009; del Río et al. 2014). The fact that beech benefits from the presence of fir in the size-symmetric component (i.e., lower inter- than intra-specific competition for belowground

This article is protected by copyright. All rights reserved. 
resources) might be explained by assuming that this broadleaf species profits from the hydraulic redistribution of water taken up by the deep root system of silver fir (Magh et al. 2017). Furthermore, the difference between the intra- and inter-specific coefficients are larger for asymmetric than symmetric competition. This implies that the composition of larger competitors is very important for beech and suggests that how species are stratified is key for modulating the growth of this species (Pretzsch \& Schutze 2005). The influence of the species composition of competitors on beech growth is also confirmed by Bayer et al. (2013), who showed that crown morphological traits of conifers such as spruce do not change from pure to mixed stands but beech admixed with spruce can significantly increase its growing space by penetrating more crown space compared to monospecific beech stands.

Lastly, as also shown by Coates et al. (2009) for North American temperate tree species, our results highlight the unbalanced feature of pairwise competitive interactions for spruce, fir and beech (i.e., the effect of species A on B can be quite different than the effect of species B on A) particularly for size-symmetric competition (coefficients $\mathrm{BA}_{\mathrm{ss}}$ ). For example, the negative effect of beech's sizesymmetric competition on fir and spruce's growth was much stronger than the effect of fir and spruce's size-symmetric competition on beech's growth.

\section{Changes of competitive interactions from two-to three-species mixtures}

With the exception of the meta-analysis by Pretzsch and Forrester (2017), we could not find much information in the literature on species interactions in three-species mixtures. Pretzsch and Forrester (2017) showed that productivity in spruce-fir-beech mixtures can be $120 \%$ of their respective monoculture and that the productivity gain can be higher than in two-species mixtures. Their investigation, however, focused on the stand-level mean mixing effects rather than at the individual tree level. At the species level, Pretzsch et al. (2013b) demonstrated that only silver fir does not benefit from growing in spruce-fir-beech mixtures. Analogously, our results suggest that an increase in productivity in a spruce-fir-beech mixture is likely due to an enhanced growth of beech and - if the proportion of beech remains below a certain threshold - spruce. Differently, the growth of fir was found to be always reduced in the three-species mixture, with stronger reductions at higher amounts of beech (Fig. 2).

To our knowledge, our investigation was the first attempt to purposely explore changes of species interactions from two to three-species mixtures. We found no significant changes in species interactions for spruce from two- to three-species mixtures, indicating that the relative proportion between the two other admixed species - fir and beech - does not have an influence on spruce's growth. Differently, in the case of fir the interaction term between inter-specific indices of symmetric competition was included in the best model, implying that the relative proportion between the amounts in basal area of spruce and beech in the three-species mixture significantly affects the growth of fir. However, this effect does not alter the main pattern of intra- and inter-specific size-symmetric competition for this species (Fig. 2b). The effect of the interaction term was more evident for beech;

This article is protected by copyright. All rights reserved. 
at increasing BAL, beech's growth was more negatively affected when larger competitors were composed of spruce and fir (in a $50 \%-50 \%$ or $80 \%-20 \%$ proportion) rather than of fir only. Nevertheless, these differences are evident only if larger competitors are composed of the two conifers. As soon as beech is present among the larger competitors, the effect of the interaction between $\mathrm{BAL}_{\mathrm{ss}, \text { spruce }}$ and $\mathrm{BAL}_{\mathrm{ss}}$, fir is small compared to the differences between intra- and inter-specific competition, and does only marginally affect patterns of SAME. Our results highlight the need for considering the interaction between the two other admixed species and the importance of vertical species stratification when modelling the complex structure, dynamics and species interactions in three-species mixtures.

\section{Methodological aspects}

Several authors demonstrated that species interactions change depending on site and climatic conditions (Toigo et al. 2015; Forrester \& Bauhus 2016; Mina et al. 2018) and others concluded that the mode of competition can vary spatially along ecological gradients (Hara 1993; Pretzsch \& Biber 2010). Here we deliberately did not investigate how SSME and SAME are modulated by site and climatic conditions. We acknowledge that exploring interaction terms between competition indices and the other site-dependent variables could have revealed interesting patterns of SSME and SAME in relation to site conditions, thus we recommend further investigations on this aspect. Nonetheless, it is worth mentioning that our results are based on a representative dataset encompassing a large geographical area, thus covering large parts of the ecological gradients of temperate Central European spruce-fir-beech forests. Our outcomes provided useful insights on mixing effects and how these can be explained depending on the different modes of competition. However, we focussed on possible explanations of these effects on growth performance as our dataset was not suitable for identifying the physiological mechanisms that lie behind competitive interactions. Additionally, while aboveground competition involves one single resource (light), plants compete belowground for a wide range of resources such as water, oxidation state, occupation of soil space and a range of nutrients (Casper \& Jackson 1997). Although our investigation was based on the broadly recognized concept of the symmetry of competition (Larocque et al. 2011), we acknowledge the complexity of processes and mechanisms that drive competition symmetry (Schwinning \& Weiner 1998; Weiskittel et al. 2011). Lastly, residuals in our models show some degree of heteroscedasticity (Fig. S4). We acknowledge that this might be worth further investigations. However, since it likely did not affect the ecological interpretation of the results, we decided not to address this aspect further.

\section{Conclusions}

Our results demonstrate the importance of considering the symmetry of competition alongside with species competitive interactions in functions of individual tree models that aim at depicting growth in 
mixed-species forests. Although we acknowledge the potential for further improvements, our approach could be integrated in forest scenario models fitted on nation-wide inventory data (e.g., Barreiro et al. 2016; Temperli et al. 2017), allowing to infer whether complementary effects occur mainly at below- or aboveground level. Also, our analysis indicates that competitive interactions for spruce and fir are likely more relevant on the size-symmetric component and that being a strong selfcompetitor for both aboveground and belowground resources, beech generally benefits of admixture with spruce and fir in temperate Central European mixed forests. Only for silver fir and beech we found significant changes in species interactions from two- to three-species mixture, but these are not as prominent as the effects due to differences between intra- and inter-specific competition. We recommend that forest productivity models - whether statistical or mechanistic - aiming at projecting growth in mixed-species systems should not only explicitly consider mixing effects but also the symmetry of competition. Improved modelling of competitive interactions can help to better evaluate adaptation measures for mixed forests under global change stressors.

\section{Acknowledgements}

The authors are thankful to the team at the Swiss NFI for the fieldwork and the data management. We are also grateful to Jan Remund and Beat Rihm from MeteoTest for the interpolated climate and nitrogen deposition data and to David I. Forrester for helpful discussions. We thank two anonymous reviewers for helpful comments that improved the quality of the paper. This work has been supported by a grant from the Swiss State Secretariat for Education, Research and Innovation (SERI) for the project "Integrating Species Mixtures in Tree Growth Functions for Forest Development Models in Switzerland" (Swiss-SpeMixMod) under the framework of the COST Action FP1206 EuMIXFOR of the European Union.

This article is protected by copyright. All rights reserved. 


\section{Figures}
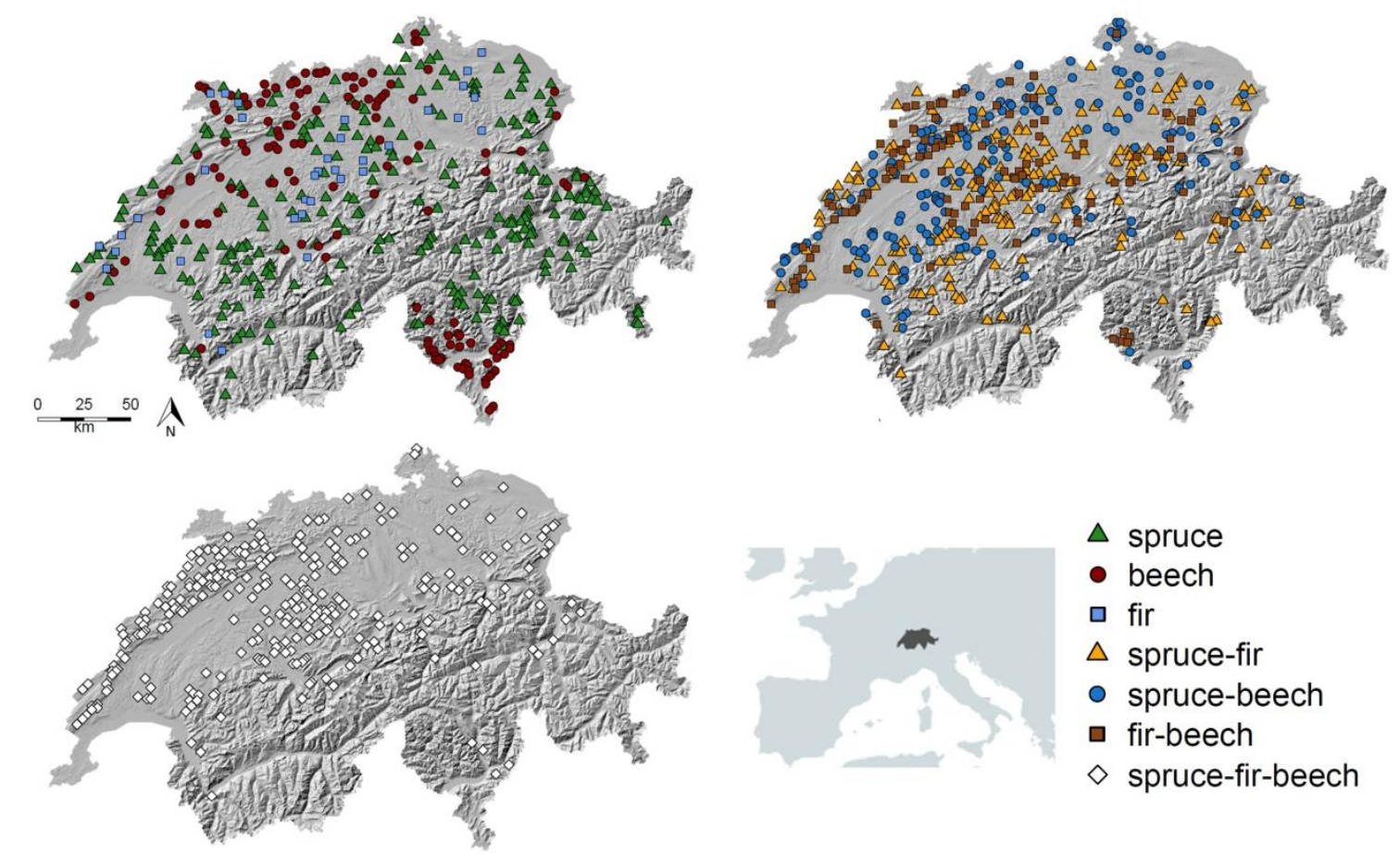

$\Delta$ spruce

- beech

口 fir

$\triangle$ spruce-fir

- spruce-beech

口 fir-beech

$\diamond$ spruce-fir-beech

Fig.1 Distribution of the NFI sample plots in Switzerland based on their species composition at the time of the NFI1 (upper-left panel: monospecific plots; upper-right: two-species mixtures; lower-left: three-species mixture) and geographical location of the study region. Source digital height model: Federal Office of Topography swisstopo.

This article is protected by copyright. All rights reserved. 

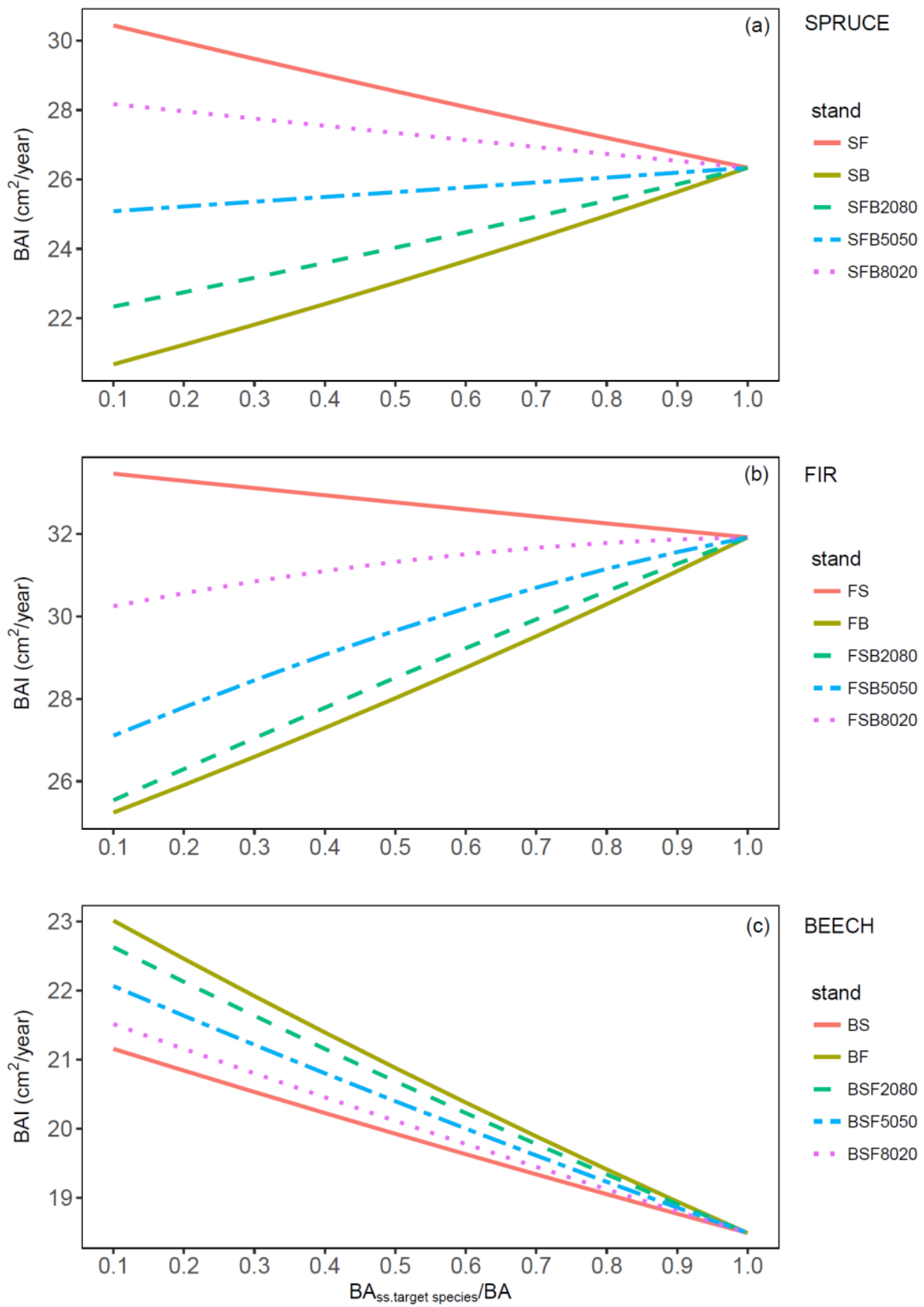

Fig.2. Effect of decreasing mixture in the size-symmetric component. Results are displayed for a dominant tree $(\mathrm{BAL}=0)$ with $\mathrm{DBH} 30 \mathrm{~cm}$ and for total stand basal of $30 \mathrm{~m}^{2} / \mathrm{ha}$. Species: $\mathrm{S}=$ spruce; $\mathrm{F}=\mathrm{fir} ; \mathrm{B}=$ beech. BAI calculated for increasing proportions of the target species $\left(\mathrm{BA}_{\mathrm{SS} \text {.target species }} / \mathrm{BA}=1\right.$ indicate a pure stand) in different stand types: $\mathrm{SF}=$ spruce-fir (no beech); $\mathrm{SB}=$ spruce-beech (no fir); SFB2080: spruce-fir-beech in which fir and beech maintain a proportions of $20 \%$ and $80 \%$ respectively of the remaining basal area; SFB5050: spruce-fir-beech in which fir and beech maintain a proportions of 50\% and 50\% respectively; SFB 8020 : sprucefir-beech in which fir and beech maintain a proportions of $80 \%$ and $20 \%$. Same concept for the other stand types. All other climatic and site variables were fixed at their mean (data in Appendix S3).

This article is protected by copyright. All rights reserved. 


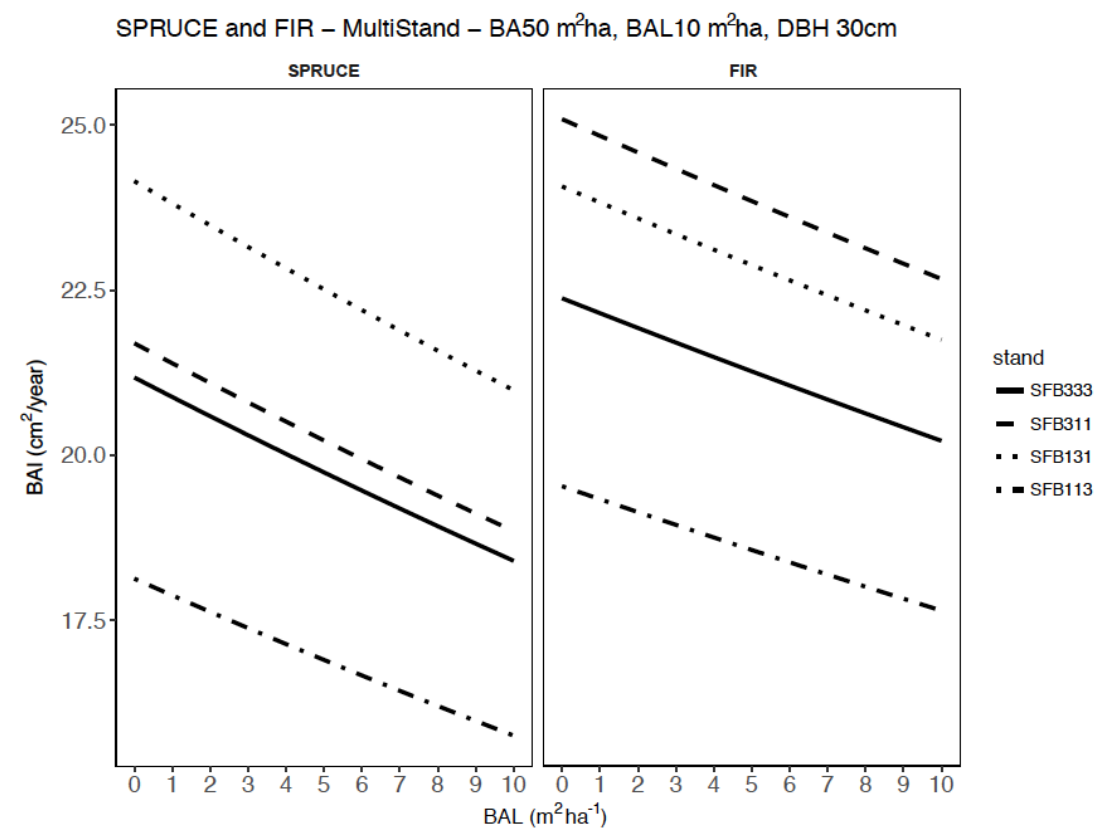

Fig.3. Predicted effect of increasing size-asymmetric competition (BAL) on a spruce and fir tree with DBH 30 $\mathrm{cm}$ in a stand with total basal area $50 \mathrm{~m}^{2} \mathrm{ha}^{-1}$ composed equally of spruce, fir and beech (SFB333, solid line, $16.67 \mathrm{~m}^{2} \mathrm{ha}^{-1}$ each), more spruce and less fir and beech (SFB311, dashed line, spruce $30 \mathrm{~m}^{2} \mathrm{ha}^{-1}$, fir and beech 10 $\mathrm{m}^{2} \mathrm{ha}^{-1}$ each), more fir and less spruce and beech (SFB131, dotted line, fir $30 \mathrm{~m}^{2} \mathrm{ha}^{-1}$, spruce and beech $10 \mathrm{~m}^{2} \mathrm{ha}^{-1}$ each), more beech and less spruce and fir (SFB113, dot-dashed line, beech $30 \mathrm{~m}^{2} \mathrm{ha}^{-1}$, spruce and fir $10 \mathrm{~m}^{2} \mathrm{ha}^{-1}$ each). All other climatic and site variables were fixed at their mean (data in Appendix S3).

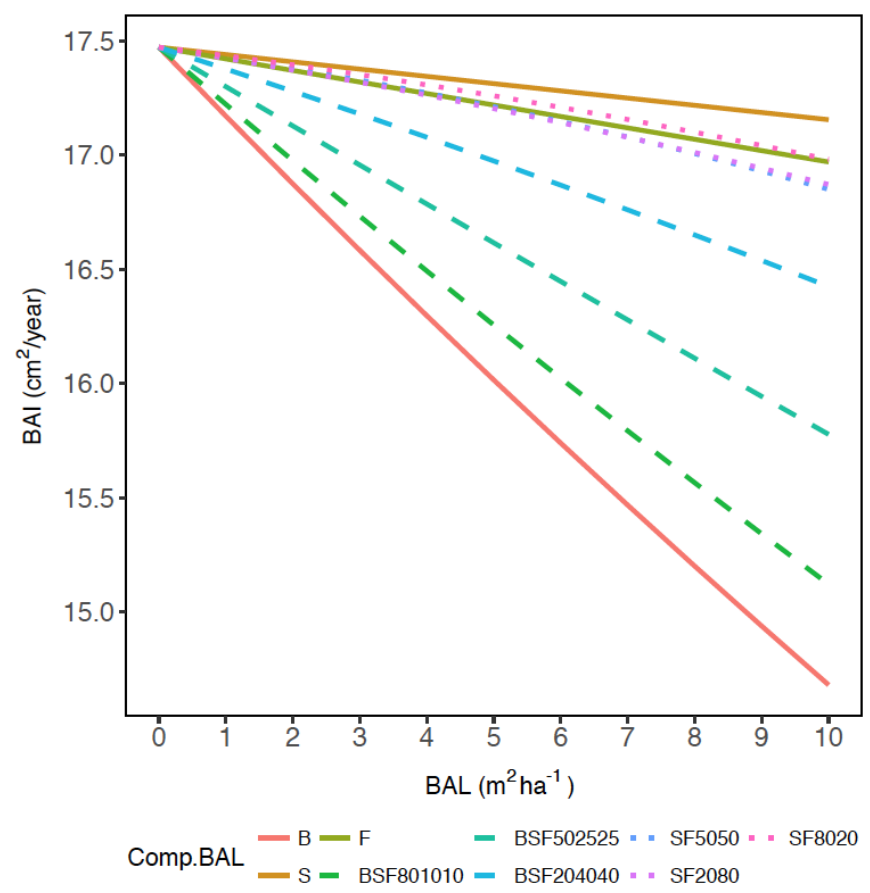

Fig.4. Predicted effect of increasing size-asymmetric competition (BAL) for beech when larger competitors are composed of: one species (solid lines; B=beech, F=fir, S=spruce), spruce and fir (dotted lines; SF5050: 50\% spruce-50\% fir; SF2080: 20\% spruce-80\% fir; SF8020: 80\% spruce-20\% fir); beech-spruce-fir (BSF801010: 80\% beech-10\% spruce-10\% fir; BSF502525: 50\% beech-25\% spruce-25\% fir; BSF204040: 20\% beech-40\% spruce- $40 \%$ fir). BAI was calculated for a tree with DBH $30 \mathrm{~cm}$ in a stand with total basal area $50 \mathrm{~m}^{2} \mathrm{ha}^{-1}$ 
composed equally of spruce, fir and beech $\left(16.66 \mathrm{~m}^{2} \mathrm{ha}^{-1}\right.$ each). All other climatic and site variables were fixed at their mean (data in Appendix S3).

\section{Tables}

Table 1. Tree- and plot-level characteristics of the dataset used in this study. Values following the symbol \pm indicate the standard deviation. Our dataset includes measurements from multiple NFI surveys; those plots that changed mixing category between two successive surveys (252 plots) were included in more than one stand type. Ranges of species-specific basal area and basal area of trees larger than the target tree are shown in Fig.S2.

\begin{tabular}{|c|c|c|c|c|c|c|c|c|c|c|c|c|c|}
\hline & \multicolumn{3}{|c|}{ Monospecific } & \multicolumn{2}{|c|}{ Spruce-Fir } & \multicolumn{2}{|c|}{ Spruce-Beech } & \multicolumn{2}{|c|}{ Fir-Beech } & \multicolumn{3}{|c|}{ Spruce-Fir-Beech } & \multirow{2}{*}{$\begin{array}{c}\text { TOTAL } \\
\text { Total }\end{array}$} \\
\hline & Spruce & Fir & Beech & Spruce & Fir & Spruce & Beech & Fir & Beech & Spruce & Fir & Beech & \\
\hline N. BAI obs. & 6352 & 667 & 3000 & 3426 & 2473 & 2500 & 2025 & 667 & 1408 & 3112 & 2878 & 2385 & 30893 \\
\hline BAI $\left(\mathrm{cm}^{2} \mathrm{yr}^{-1}\right)$ & $\begin{array}{c}21.2 \\
\pm 18.3\end{array}$ & $\begin{array}{c}37.5 \\
\pm 30.7\end{array}$ & $\begin{array}{c}16.5 \\
\pm 17.3\end{array}$ & $\begin{array}{c}23.7 \\
\pm 19.4\end{array}$ & $\begin{array}{c}30.4 \\
\pm 27.0\end{array}$ & $\begin{array}{c}23.7 \\
\pm 20.2\end{array}$ & $\begin{array}{c}17.6 \\
\pm 17.2\end{array}$ & $\begin{array}{c}29.6 \\
\pm 28.3\end{array}$ & $\begin{array}{c}19.1 \\
\pm 16.4\end{array}$ & $\begin{array}{c}24.0 \\
\pm 21.1\end{array}$ & $\begin{array}{c}26.9 \\
\pm 26.6\end{array}$ & $\begin{array}{c}16.6 \\
\pm 16.5\end{array}$ & $\begin{array}{c}22.6 \\
\pm 21.4\end{array}$ \\
\hline N. plots & 358 & 79 & 215 & \multicolumn{2}{|c|}{303} & \multicolumn{2}{|c|}{244} & \multicolumn{2}{|c|}{174} & \multicolumn{3}{|c|}{371} & 1492 \\
\hline $\begin{array}{l}\text { Stand basal } \\
\text { area }\left(\mathrm{m}^{2} \mathrm{ha}^{-1}\right)\end{array}$ & $\begin{array}{c}40.0 \\
\pm 17.7\end{array}$ & $\begin{array}{c}34.1 \\
\pm 13.3\end{array}$ & $\begin{array}{c}31.4 \\
\pm 12.6\end{array}$ & \multicolumn{2}{|c|}{$42.7 \pm 15.4$} & \multicolumn{2}{|c|}{$39.9 \pm 15.6$} & \multicolumn{2}{|c|}{$33.2 \pm 13.3$} & \multicolumn{3}{|c|}{$41.4 \pm 13.2$} & $\begin{array}{c}39.3 \\
\pm 15.3\end{array}$ \\
\hline $\begin{array}{l}\text { Elevation } \\
\text { (m a.s.1.) }\end{array}$ & $\begin{array}{l}1071 \\
\pm 333\end{array}$ & $\begin{array}{c}827 \\
\pm 231\end{array}$ & $\begin{array}{c}857 \pm \\
289\end{array}$ & \multicolumn{2}{|c|}{$969 \pm 263$} & \multicolumn{2}{|c|}{$836 \pm 261$} & \multicolumn{2}{|c|}{$876 \pm 220$} & \multicolumn{3}{|c|}{$908 \pm 225$} & $\begin{array}{c}933 \\
\pm 280\end{array}$ \\
\hline $\begin{array}{l}\text { Annual mean } \\
\text { temperature } \\
\left({ }^{\circ} \mathrm{C}\right)\end{array}$ & $\begin{array}{c}6.6 \\
\pm 1.7\end{array}$ & $\begin{array}{c}7.9 \\
\pm 1.2\end{array}$ & $\begin{array}{c}8.0 \\
\pm 1.2\end{array}$ & \multicolumn{2}{|c|}{$7.1 \pm 1.4$} & \multicolumn{2}{|c|}{$7.8 \pm 1.3$} & \multicolumn{2}{|c|}{$7.6 \pm 1.2$} & \multicolumn{3}{|c|}{$7.4 \pm 1.2$} & $\begin{array}{c}7.3 \\
\pm 1.4\end{array}$ \\
\hline $\begin{array}{l}\text { Annual } \\
\text { precipitation } \\
(\mathrm{mm})\end{array}$ & $\begin{array}{l}1394 \\
\pm 303\end{array}$ & $\begin{array}{l}1371 \\
\pm 204\end{array}$ & $\begin{array}{r}1409 \\
\pm 339\end{array}$ & \multicolumn{2}{|c|}{$1481 \pm 286$} & \multicolumn{2}{|c|}{$1372 \pm 292$} & \multicolumn{2}{|c|}{$1442 \pm 255$} & \multicolumn{3}{|c|}{$1441 \pm 245$} & $\begin{array}{l}1423 \\
\pm 285\end{array}$ \\
\hline
\end{tabular}

This article is protected by copyright. All rights reserved. 
Table 2. Estimated coefficients with their standard deviations and p-values for the three final models for spruce, fir and beech. Last rows report fit statistics (root mean square error RMSE in $\mathrm{cm}^{2} \mathrm{ha}^{-1} \mathrm{yr}^{-1}$, percentage bias PBIAS and $\mathrm{R}^{2}$ between observations and model predictions with and without random effects). Empty cells denote variables not included in the models because previously excluded by Rohner et al. (2017) or during model selection in the current study.

\begin{tabular}{|c|c|c|c|c|c|c|}
\hline \multirow[t]{2}{*}{ Variable } & \multicolumn{2}{|c|}{ Spruce } & \multicolumn{2}{|l|}{ Fir } & \multicolumn{2}{|c|}{ Beech } \\
\hline & Coefficient & $\mathrm{P}$ & Coefficient & $\mathrm{P}$ & Coefficient & $\mathrm{P}$ \\
\hline b1 & $3.218 \pm 0.086$ & $<0.001$ & $4.081 \pm 0.147$ & $<0.001$ & $3.844 \pm 0.137$ & $<0.001$ \\
\hline b2 (DBH) & $-0.048 \pm 0.002$ & $<0.001$ & $-0.051 \pm 0.003$ & $<0.001$ & $-0.054 \pm 0.003$ & $<0.001$ \\
\hline$\beta_{0}$ & $-0.876 \pm 0.426$ & 0.040 & $0.279 \pm 0.240$ & 0.245 & $-2.199 \pm 0.512$ & $<0.001$ \\
\hline st.dev. $b_{\text {plot }}$ [residuals] & $0.328[12.71]$ & - & $0.370[16.37]$ & - & $0.310[10.21]$ & - \\
\hline DDOM & $-0.005 \pm 0.001$ & $<0.001$ & $-0.003 \pm 0.002$ & 0.065 & $-0.006 \pm 0.001$ & $<0.001$ \\
\hline RE & $0.197 \pm 0.099$ & 0.047 & & & & \\
\hline TYP & & & & & $-0.044 \pm 0.023$ & 0.059 \\
\hline SLP & $-0.002 \pm 0.001$ & $<0.001$ & $-0.005 \pm 0.001$ & $<0.001$ & $-0.033 \pm 0.001$ & $<0.001$ \\
\hline NORTH & $0.050 \pm 0.016$ & 0.002 & & & & \\
\hline CURV & $0.087 \pm 0.052$ & 0.090 & & & $0.082 \pm 0.052$ & 0.114 \\
\hline AWC & $0.002 \pm 0.000$ & $<0.001$ & $0.002 \pm 0.001$ & $<0.001$ & & \\
\hline TEMP & $0.102 \pm 0.009$ & $<0.001$ & $0.090 \pm 0.012$ & $<0.001$ & $0.115 \pm 0.012$ & $<0.001$ \\
\hline MI & $1.125 \pm 0.313$ & $<0.001$ & & & $1.399 \pm 0.361$ & $<0.001$ \\
\hline SR & $0.0004 \pm 0.000$ & $<0.001$ & & & $0.0004 \pm 0.000$ & 0.001 \\
\hline NDEP & $-0.007 \pm 0.001$ & $<0.001$ & $-0.008 \pm 0.001$ & $<0.001$ & $0.008 \pm 0.002$ & $<0.001$ \\
\hline $\mathrm{PH}$ & $-0.059 \pm 0.009$ & $<0.001$ & $-0.051 \pm 0.013$ & $<0.001$ & $-0.025 \pm 0.010$ & 0.011 \\
\hline BAL & $-0.014 \pm 0.001$ & $<0.001$ & $-0.010 \pm 0.001$ & $<0.001$ & & \\
\hline $\mathrm{BA}_{\mathrm{SS}-\text { spruce }}$ & $-0.008 \pm 0.001$ & $<0.001$ & $-0.005 \pm 0.001$ & $<0.001$ & $-0.009 \pm 0.002$ & $<0.001$ \\
\hline $\mathrm{BA}_{\mathrm{SS}-\mathrm{fir}}$ & $-0.003 \pm 0.001$ & 0.027 & $-0.007 \pm 0.001$ & $<0.001$ & $-0.006 \pm 0.002$ & 0.017 \\
\hline $\mathrm{BA}_{\mathrm{SS}-\text { beech }}$ & $-0.017 \pm 0.002$ & $<0.001$ & $-0.015 \pm 0.003$ & $<0.001$ & $-0.014 \pm 0.001$ & $<0.001$ \\
\hline $\mathrm{BA}_{\mathrm{SS} \text {-spruce }}: \mathrm{BA}_{\mathrm{SS} \text {-beech }}$ & & & $-0.0004 \pm 0.000$ & 0.083 & & \\
\hline $\mathrm{BAL}_{\mathrm{SS} \text {-spruce }}$ & & & & & $-0.002 \pm 0.002$ & 0.382 \\
\hline $\mathrm{BAL}_{\mathrm{SS}-\text { fir }}$ & & & & & $-0.003 \pm 0.003$ & 0.337 \\
\hline BAL $_{\text {SS-beech }}$ & & & & & $-0.017 \pm 0.001$ & $<0.001$ \\
\hline $\mathrm{BAL}_{\mathrm{SS} \text {-spruce }}: \mathrm{BAL}_{\mathrm{SS} \text {-fir }}$ & & & & & $-0.0005 \pm 0.001$ & 0.009 \\
\hline$R M S E$ & 12.35 & & 15.7 & & 9.8 & \\
\hline$P-B I A S$ & 1.7 & & 2.2 & & 2.0 & \\
\hline$R_{\text {all effects }}^{2}$ & 0.59 & & 0.67 & & 0.66 & \\
\hline$R_{\text {fixed effects }}^{2}$ & 0.40 & & 0.45 & & 0.48 & \\
\hline
\end{tabular}

DBH: diameter at breast height; DDOM: mean of the 100 largest diameters per ha; RE: release effect due to management; SLP: slope of the plot; NORTH: northness index; CURV: profile curvature; AWC: available soil water holding capacity; TEMP: temperature; MI: moisture index (ETa/ETp); SR: global solar radiation; NDEP: nitrogen deposition; PH: soil pH; BAL: basal area of trees larger than the target tree; $\mathrm{BA}_{\mathrm{SS}}$ basal area of trees of a given species within the sampling plot of the target tree; $\mathrm{BAL}_{\mathrm{SS}}$ basal area of trees of a given species larger than the target tree. See Appendix S2 for further information.

This article is protected by copyright. All rights reserved. 


\section{Supporting Information}

Additional Supporting Information may be found in the online version of this article:

Appendix S1. Additional figures and tables

Figure S1. Difference in temperature range for pure spruce plots including and excluding the subalpine vegetation zone.

Table S1. Number of sampling plots between two consecutive NFIs by altitudinal vegetation zones in Switzerland.

Figure S2. Ranges of species-specific basal area $\left(\mathrm{BA}_{\mathrm{SS}}\right)$ for each target species growing in pure stands, two- and three-species mixture.

Figure S3. Ranges of species-specific basal area of trees larger than the target tree $\left(\mathrm{BAL}_{\mathrm{SS}}\right)$ growing in pure stands, two- and three-species mixture.

Table S2. Models for BAI of spruce, fir and beech with different competition structures ranked according to their AICc.

Figure S4. Comparison of observed and predicted basal area increments of the selected models for the three species.

Table S3. Overview of the variables composing the fixed effects of the final models.

Appendix S2. Additional information on the Swiss NFI, plots selection, explanatory variables, competition indices and model selection.

Appendix S3. Stand/species composition scenarios with varying $\mathrm{BA}_{S S}$ and $B \mathrm{BL}_{\mathrm{SS}}$, including climatic and site variables and estimated BAI values (files in TXT format).

This article is protected by copyright. All rights reserved. 


\section{References}

Ammer, C. 2017. Unraveling the Importance of Inter- and Intraspecific Competition for the Adaptation of Forests to Climate Change. In: Cánovas, F.M., Lüttge, U. \& Matyssek, R. (eds.) Progress in Botany Vol. 78, pp. 345-367. Springer International Publishing, Cham.

Barreiro, S., Schelhaas, M.-J., Kändler, G., Antón-Fernández, C., Colin, A., Bontemps, J.-D., Alberdi, I., Condés, S., Dumitru, M., Ferezliev, A., Fischer, C., Gasparini, P., Gschwantner, T., Kindermann, G., Kjartansson, B., Kovácsevics, P., Kucera, M., Lundström, A., Marin, G., Mozgeris, G., Nord-Larsen, T., Packalen, T., Redmond, J., Sacchelli, S., Sims, A., Snorrason, A., Stoyanov, N., Thürig, E. \& Wikberg, P.-E. 2016. Overview of methods and tools for evaluating future woody biomass availability in European countries. Annals of Forest Science 73: 823837.

Bauhus, J., Forrester, D.I., Gardiner, B., Jactel, H., Vallejo, R. \& Pretzsch, H. 2017. Ecological Stability of Mixed-Species Forests. In: Pretzsch, H., Forrester, D.I. \& Bauhus, J. (eds.) Mixed-Species Forests: Ecology and Management, pp. 337-382. Springer Berlin Heidelberg, Berlin, Heidelberg.

Bauhus, J., van Winden, A.P. \& Nicotra, A.B. 2004. Aboveground interactions and productivity in mixed-species plantations of Acacia mearnsii and Eucalyptus globulus. Canadian Journal of Forest Research 34: 686-694.

Bayer, D., Seifert, S. \& Pretzsch, H. 2013. Structural crown properties of Norway spruce (Picea abies [L.] Karst.) and European beech (Fagus sylvatica [L.]) in mixed versus pure stands revealed by terrestrial laser scanning. Trees-Structure and Function 27: 1035-1047.

Bolte, A., Kampf, F. \& Hilbrig, L. 2013. Space sequestration below ground in old-growth spruce-beech forests - signs for faclitation? Frontiers in Plant Science 4.

Bolte, A. \& Villanueva, I. 2006. Interspecific competition impacts on the morphology and distribution of fine roots in European beech (Fagus sylvatica L.) and Norway spruce (Picea abies (L.) Karst.). European Journal of Forest Research 125: 15-26.

Bosela, M., Tobin, B., Seben, V., Petras, R. \& Larocque, G.R. 2015. Different mixtures of Norway spruce, silver fir, and European beech modify competitive interactions in central European mature mixed forests. Canadian Journal of Forest Research 45: 1577-1586.

Bourdier, T., Cordonnier, T., Kunstler, G., Piedallu, C., Lagarrigues, G. \& Courbaud, B. 2016. Tree Size Inequality Reduces Forest Productivity: An Analysis Combining Inventory Data for Ten European Species and a Light Competition Model. PLoS One 11.

Burnham, K.P. \& Anderson, D. 2003. Model Selection and Multimodel Inference - A Practical Information-Theoretic Approach. Springer-Verlag, New York, USA.

Büttner, V. \& Leuschner, C. 1994. Spatial and temporal patterns of fine root abundance in a mixed oak-beech forest. Forest Ecology and Management 70: 11-21.

Casper, B.B. \& Jackson, R.B. 1997. Plant competition underground. Annual Review of Ecology and Systematics 28: 545-570.

Cavard, X., Bergeron, Y., Chen, H.Y.H., Pare, D., Laganiere, J. \& Brassard, B. 2011. Competition and facilitation between tree species change with stand development. Oikos 120: 1683-1695.

Coates, K.D., Canham, C.D. \& LePage, P.T. 2009. Above- versus below-ground competitive effects and responses of a guild of temperate tree species. Journal of Ecology 97: 118-130.

Cordonnier, T. \& Kunstler, G. 2015. The Gini index brings asymmetric competition to light. Perspectives in Plant Ecology Evolution and Systematics 17: 107-115.

Curt, T. \& Prévosto, B. 2003. Rooting strategy of naturally regenerated beech in Silver birch and Scots pine woodlands. Plant and Soil 255: 265-279.

del Río, M., Condes, S. \& Pretzsch, H. 2014. Analyzing size-symmetric vs. size-asymmetric and intravs. inter-specific competition in beech (Fagus sylvatica L.) mixed stands. Forest Ecology and Management 325: 90-98.

This article is protected by copyright. All rights reserved. 
Ellenberg, H. 1988. Vegetation ecology of Central Europe.4th ed. Cambridge University Press, Cambridge ; New York.

Fares, S., Mugnozza, G.S., Corona, P. \& Palahi, M. 2015. Sustainability: Five steps for managing Europe's forests. Nature 519: 407-409.

Forrester, D.I. 2014. The spatial and temporal dynamics of species interactions in mixed-species forests: From pattern to process. Forest Ecology and Management 312: 282-292.

Forrester, D.I. \& Albrecht, A.T. 2014. Light absorption and light-use efficiency in mixtures of Abies alba and Picea abies along a productivity gradient. Forest Ecology and Management 328: 94102.

Forrester, D.I. \& Bauhus, J. 2016. A Review of Processes Behind Diversity-Productivity Relationships in Forests. Current Forestry Reports 2: 45-61.

Forrester, D.I., Kohnle, U., Albrecht, A.T. \& Bauhus, J. 2013. Complementarity in mixed-species stands of Abies alba and Picea abies varies with climate, site quality and stand density. Forest Ecology and Management 304: 233-242.

Gamfeldt, L., Snall, T., Bagchi, R., Jonsson, M., Gustafsson, L., Kjellander, P., Ruiz-Jaen, M.C., Froberg, M., Stendahl, J., Philipson, C.D., Mikusinski, G., Andersson, E., Westerlund, B., Andren, H., Moberg, F., Moen, J. \& Bengtsson, J. 2013. Higher levels of multiple ecosystem services are found in forests with more tree species. Nat Commun 4: 1340.

Hara, T. 1993. Mode of Competition and Size-structure Dynamics in Plant Communities. Plant Species Biology 8: 75-84.

Huber, M.O., Sterba, H. \& Bernhard, L. 2014. Site conditions and definition of compositional proportion modify mixture effects in Picea abies - Abies alba stands. Canadian Journal of Forest Research 44: 1281-1291.

Kaufmann, E. 2001. Estimation of standing timber, growth and cut. In: Brassel, P. \& Lischke, H. (eds.) Swiss National Forest Inventory: Methods and Models of the Second Assessment, pp. 162196. Swiss Federal Research Institute WSL, Birmensdorf.

Knoke, T., Ammer, C., Stimm, B. \& Mosandl, R. 2008. Admixing broadleaved to coniferous tree species: a review on yield, ecological stability and economics. European Journal of Forest Research 127: 89-101.

Larocque, G.R., Archambault, L. \& Delisle, C. 2011. Development of the gap model ZELIG-CFS to predict the dynamics of North American mixed forest types with complex structures. Ecological Modelling 222: 2570-2583.

Larocque, G.R., Luckai, N., Adhikary, S.N., Groot, A., Bell, F.W. \& Sharma, M. 2013. Competition theory - science and application in mixed forest stands: review of experimental and modelling methods and suggestions for future research. Environmental Reviews 21: 71-84.

Lebourgeois, F., Gomez, N., Pinto, P. \& Merian, P. 2013. Mixed stands reduce Abies alba tree-ring sensitivity to summer drought in the Vosges mountains, western Europe. Forest Ecology and Management 303: 61-71.

Magh, R.-K., Grün, M., Knothe, V.E., Stubenazy, T., Tejedor, J., Dannenmann, M. \& Rennenberg, H. 2017. Silver-fir (Abies alba MILL.) neighbors improve water relations of European beech (Fagus sylvatica L.), but do not affect $\mathrm{N}$ nutrition. Trees.

Manso, R., Morneau, F., Ningre, F. \& Fortin, M. 2015. Effect of climate and intra- and inter-specific competition on diameter increment in beech and oak stands. Forestry 88: 540-551.

Mina, M., Huber, M.O., Forrester, D.I., Thürig, E. \& Rohner, B. 2018. Multiple factors modulate tree growth complementarity in Central European mixed forests. Journal of Ecology 106: 11061119.

Pinheiro, J. \& Bates, D. 2000. Mixed-effects models in S and S-PLUS. Springer Science \& Business Media.

Pinheiro, J., Bates, D., DebRoy, S., Sarkar, D. \& Team, R.C. 2017. nlme: Linear and Nonlinear Mixed Effects Models. R package version 3.1-131. https://CRAN.R-project.org/package=nlme. In.

This article is protected by copyright. All rights reserved. 
Pretzsch, H. 2014. Canopy space filling and tree crown morphology in mixed-species stands compared with monocultures. Forest Ecology and Management 327: 251-264.

Pretzsch, H. \& Biber, P. 2010. Size-symmetric versus size-asymmetric competition and growth partitioning among trees in forest stands along an ecological gradient in central Europe. Canadian Journal of Forest Research-Revue Canadienne De Recherche Forestiere 40: 370384.

Pretzsch, H., Biber, P., Uhl, E. \& Dauber, E. 2015. Long-term stand dynamics of managed spruce-firbeech mountain forests in Central Europe: structure, productivity and regeneration success. Forestry 88: 407-428.

Pretzsch, H., Bielak, K., Block, J., Bruchwald, A., Dieler, J., Ehrhart, H.-P., Kohnle, U., Nagel, J., Spellmann, H., Zasada, M. \& Zingg, A. 2013a. Productivity of mixed versus pure stands of oak (Quercus petraea (Matt.) Liebl. and Quercus robur L.) and European beech (Fagus sylvatica L.) along an ecological gradient. European Journal of Forest Research 132: 263-280.

Pretzsch, H., Bielak, K., Bruchwald, A., Dieler, J., Dudzinska, M., Ehrhart, H.-P., Jensen, A., Johannsen, V.K., Kohnle, U. \& Nagel, J. 2013b. Species mixing and productivity of forests. Results from long-term experiments. German title: Mischung und Produktivität von Waldbeständen. Ergebnisse langfristiger ertragskundlicher Versuche: Aus dem Lehrstuhl für Waldwachstumskunde der Technischen Universität München. Allgemeine Forst-Und Jagdzeitung 184: 177-196.

Pretzsch, H., Block, J., Dieler, J., Dong, P.H., Kohnle, U., Nagel, J., Spellmann, H. \& Zingg, A. 2010. Comparison between the productivity of pure and mixed stands of Norway spruce and European beech along an ecological gradient. Annals of Forest Science 67.

Pretzsch, H. \& Forrester, D.I. 2017. Stand Dynamics of Mixed-Species Stands Compared with Monocultures. In: Pretzsch, H., Forrester, D.I. \& Bauhus, J. (eds.) Mixed-Species Forests: Ecology and Management, pp. 117-209. Springer Berlin Heidelberg, Berlin, Heidelberg.

Pretzsch, H. \& Schutze, G. 2005. Crown allometry and growing space efficiency of Norway spruce (Picea abies [L.] Karst.) and European beech (Fagus sylvatica L.) in pure and mixed stands. Plant Biology 7: 628-639.

Pretzsch, H. \& Schutze, G. 2016. Effect of tree species mixing on the size structure, density, and yield of forest stands. European Journal of Forest Research 135: 1-22.

R Core Team 2017. R: A Language and Environment for Statistical Computing. In. R Foundation for Statistical Computing. URL http://www.R-project.org, Vienna, Austria.

Reineke, L.H. 1933. Perfecting a stand-density index for evenaged forests. Journal of Agricultural Research 46: 0627-0638.

Rewald, B. \& Leuschner, C. 2009. Belowground competition in a broad-leaved temperate mixed forest: pattern analysis and experiments in a four-species stand. European Journal of Forest Research 128: 387-398.

Riofrio, J., del Rio, M. \& Bravo, F. 2017. Mixing effects on growth efficiency in mixed pine forests. Forestry: An International Journal of Forest Research 90: 381-392.

Rohner, B., Waldner, P., Lischke, H., Ferretti, M. \& Thürig, E. 2017. Predicting individual-tree growth of central European tree species as a function of site, stand, management, nutrient and climate effects. European Journal of Forest Research First online: 30.11.2017.

Rohner, B., Weber, P. \& Thürig, E. 2016. Bridging tree rings and forest inventories: How climate effects on spruce and beech growth aggregate over time. Forest Ecology and Management 360: 159-169.

Rothe, A. \& Binkley, D. 2001. Nutritional interactions in mixed species forests: a synthesis. Canadian Journal of Forest Research-Revue Canadienne De Recherche Forestiere 31: 1855-1870.

Schwinning, S. \& Weiner, J. 1998. Mechanisms determining the degree of size asymmetry in competition among plants. Oecologia 113: 447-455.

This article is protected by copyright. All rights reserved. 
Seidl, R., Spies, T.A., Peterson, D.L., Stephens, S.L. \& Hicke, J.A. 2016. Searching for resilience: addressing the impacts of changing disturbance regimes on forest ecosystem services. Journal of Applied Ecology 53: 120-129.

Temperli, C., Stadelmann, G., Thurig, E. \& Brang, P. 2017. Silvicultural strategies for increased timber harvesting in a Central European mountain landscape. European Journal of Forest Research 136: 493-509.

Thürig, E., Kaufmann, E., Frisullo, R. \& Bugmann, H. 2005. Evaluation of the growth function of an empirical forest scenario model. Forest Ecology and Management 204: 53-68.

Toigo, M., Vallet, P., Perot, T., Bontemps, J.D., Piedallu, C. \& Courbaud, B. 2015. Overyielding in mixed forests decreases with site productivity. Journal of Ecology 103: 502-512.

Traub, B., Meile, R., Speich, S. \& Rösler, E. 2017. The data storage and analysis system of the Swiss National Forest Inventory. Computers and Electronics in Agriculture 132: 97-107.

Vallet, P. \& Perot, T. 2011. Silver fir stand productivity is enhanced when mixed with Norway spruce: evidence based on large-scale inventory data and a generic modelling approach. Journal of Vegetation Science 22: 932-942.

Wagenmakers, E.J. \& Farrell, S. 2004. AIC model selection using Akaike weights. Psychonomic Bulletin \& Review 11: 192-196.

Weiner, J. 1990. Asymmetric Competition in Plant-Populations. Trends in Ecology \& Evolution 5: 360364.

Weiskittel, A.R., Hann, D.W., Kershaw, J.A. \& Vanclay, J.K. 2011. Indices of Competition. In: Forest Growth and Yield Modeling, pp. 15-36. John Wiley \& Sons, Ltd.

This article is protected by copyright. All rights reserved. 